УДК 159.923.2:316.613.4

DOI: $10.26565 / 2410-1249-2019-11-07$

\title{
THE ROLE OF EMOTIONAL INTELLIGENCE IN SELF-ACTUALIZATION OF PERSONALITY
}

\author{
Kateryna Mylashenko \\ Aspirant of the Psychology Department of Poltava V. G. Korolenko National Pedagogical University \\ https://orcid.org/0000-0002-5528-0201
}

Vitaliy Lavrinenko

Candidate of Science in Psychology (PhD), senior lecturer of the Psychology Department of Poltava V. G. Korolenko National Pedagogical University

E-mail: lavrinenko.vitaliy@gmail.com,https://orcid.org/0000-0003-4531-7127

\begin{abstract}
The article is aimed to reveal the analysis of the emotional intelligence role in adult age personality selfactualization process. The relevance of emotional intelligence and self-actualization connection study in the context of modern scientific discourses and crisis conditions of society is described. The article summarizes the results of theoretical analysis of the problem of self-actualization. The most significant features of the selfactualization process from the point of view of humanistic psychology are presented. Also, methodological principles and basic aspects of self-actualization understanding in domestic psychology are described according to the methodological principles of the activity approach. The essential features of emotional intelligence of the personality, its structure are determined. It is substantiated that emotional intelligence is connected with the process of individual's self-actualization through realization of the personality in the fullness of his own emotional life, ability to experience peak emotions, emotional sphere content control, etc. The methodological bases of the study, the specifics of the sample and the compared diagnostic groups are described. The empirical data of the person's self-actualization study, its most significant parameters, expressiveness of different aspects of emotional intelligence are analyzed. The obtained empirical data are interpreted in accordance with classical and modern scientific views on the nature of the self-actualization processes and emotional intelligence. The emotional intelligence indicators expressiveness in intra- and interpersonal plane was interpreted in two groups respondents who receive a second higher education in the specialty "Psychology" and those who aim to selfactualize. The predominance of interpersonal emotional intelligence and its components - understanding other people's emotions and managing other people's emotions - in the sample, which aim at their own selfactualization, is statistically substantiated and substantively analyzed. Also, the tendency towards identification of one's own emotional sphere content, its expression and indicator of emotional intelligence in general was expressed for both groups of the studied. On the basis of empirical data generalization the tendency of selfactualization and emotional intelligence signs combination in of personality's functioning is revealed.
\end{abstract}

KEY WORDS: self-actualization of the personality, self-actualization factors, time orientation, emotional intelligence, interpersonal and intrapersonal emotional intelligence, emotional intelligence as a factor of selfactualization

Rising of the problem. The question of the personality's self-actualization is one of the most complex and relevant in a modern society. The increased attention to this problem is caused, firstly, by the need to study the system of resources and the process of personal development in the crisis conditions of modern society (multi-vector development and self-realization, expanding consumption values in the absence of vital certainty, lack of individual's confidence in the future due to complex socio-political and economic processes of Ukrainian society, etc. (Sedykh, 2013), and secondly, the lack of a unified and comprehensive understanding of the processes of personality's self- actualization for its psychological support. Particularly actual problem of self-actualization occurs in adulthood, when the personality not only learns and develops, as in childhood and adolescence, but already has certain results of own activities, by which personality can raise the question of the effectiveness of life, it's fullness in meaning, inherent values conformity to the goals that was set at the beginning of the self-actualization process. Particularly important is the problem of the effectiveness of personality's life, the assessment of achieved goals and future perspectives, which reflects the features of self-actualization of the individual. 
Also it's important issue of distinguishing the range of self-actualization resources of an adult, among which the important role belongs to the ability to identify own emotions, to recognize the emotions of others and to manage emotional processes. These qualities reflect the emotional intelligence generated in the individual and is a significant component of self-actualized personality.

The aim of this article is to investigate the peculiarities of the emotional intelligence formation of the adults with different ways of self-actualization.

Development of the problem under investigation. The question of personality's selfactualization is one of the fundamental problems of scientific knowledge, because person joins the society, harmoniously and balancedly discloses it through the self-actualization. While personality is realizing the opportunities for the development of his "Self".

The main scientific theories of self-actualization have been developed within the approaches of such scientists as A. Adler, R. Assadjouli, A. Langle, A. Maslow, G. Allport, K. Rogers, V. Frankl, E. Fromm, K. Horney, E. Shostrom, K.G. Jung. A. Maslow, the founder of humanistic psychology, defines self-actualization as the desire of man to actualize what is contained therein as potencies. This tendency can be called the desire to become the person it can become, to reach the peak of its potential (Sedykh, 2016, p. 494]. Self-actualization by the view of E. Fromm is expressed through the notion of "effective orientation" in human life, the true self, which is understood as the installation of the realization of man's inherent opportunities, expedient to use his powers (Starins'ka, 2015). E. Fromm isolated from the five main existential needs of man (in establishing connections, overcoming, the need for roots, identity with themselves, system of views and devotion) enriched scientific ideas about the mechanisms of selfactualization.

The consideration of the problem of selfactualization in the native psychology is associated with the main provisions of the activity approach to the interpretation of the inner world of personality (P.Ya. Halperin, O.M. Leontiev, S.L. Rubinstein, K.O. Abulkhanova-Slavska, B.G. Ananiev,
A.V. Brushlinsky, etc.). The basic principles of the activity theory (reflection, objectivity, systematicity, development, determinism, etc.) allowed scientists to re-examine the concepts of foreign humanistic psychology about self-actualization and selfactualization and to reveal the nature of the mechanisms of its development. As observes (Starins'ka, 2015), the theoretical and methodological foundations of the self-actualization study in native psychology led to the understanding of the "self-actualization" phenomenon essence through the categories of "activity", "orientation", "system of relations", "individuality", "subject", "life path"; use for its interpretation of the concepts of "urgent need", "actual ability", "actual and potential characteristics of man".

An important and definitively unresolved issue in this context is the search for resources of selfactualization of the personality. Modern authors consider self-actualization in connection with various psychological phenomena and processes, focusing mainly on studying self-actualization in the context of professional formation, overcoming difficult life situations, realization in family relationships, etc.

Emotional intelligence is an important phenomenon that reflects the personality's ability to establish, maintain and interpret emotional relationships and phenomena, its management. The phenomenon of emotional intelligence is differently explained by scientists, but is mainly associated with cognitive processes, and with the process of individual life realization. That is, the abilities and manifestations that make up the emotional intelligence of the individual are both significant for the process of its self-actualization. Therefore, emotional intelligence is determined as one of the most powerful personality's self-actualization resources, reflecting the accuracy of personality's orientation in the system of emotional phenomena, their identification and guidance.

Emotional intelligence and its components understanding presented in the concepts of emotional intelligence today. First of all, it is a model of Western researchers (J. Meyer, P. Salovey and D. Caruso, R. Bar-On, (Goulman, 2009), K. Petridix and A. Fernham) $[1,4]$. It is important to note that 
despite the common terminology, scientists somewhat differently determine the essence of the emotional intelligence phenomenon. Given these differences, all existing models can be grouped into three groups: abilities models, characteristics / traits models, mixed models.

In abilities model emotional intelligence is interpreted as an intersection of emotions and cognition, that is, as a cognitive ability. Such a model is described in the theory of emotional and intellectual abilities of J. Mayer, P. Selovey, D. Caruso (Sergienko, 2010). In it, emotional intelligence acts as an ability to reflect on emotions and emotions. Emotions themselves are useful source of information that helps to navigate the social environment. This model explains that people differ in their abilities to process information of an emotional nature and correlate it with what is happening around.

More formally, J. Meyer, P. Selovey, D. Caruso defines emotional intelligence as a set of competences, which includes "the ability to accurately perceive emotions; the ability to access and generate feelings when it favors thinking; the ability to understand information about emotions and to use knowledge about emotions; the ability to manage or regulate both their own emotions and emotions of others in order to promote emotional and intellectual growth and well-being" (Sergienko, 2010).

Summarizing the actual research, we generalize that the role of emotional intelligence in the process of self-actualization of the adult age personality is most clearly and simply demonstrate in characteristics of self-actualized personality, which are allocated by different authors, and included in the scope of its emotional intelligence. In particular, such characteristics of the personality include: mystical and higher experiences (Maslow, 2007); the ability to spontaneous behaviour and expression of feelings, the adoption of aggression as a natural manifestation of human nature (E. Shostrom); openness as an expression of the desire to love and invoke love (V. Shuts); openness of experience, containing emotionality and reflection (S. Maddi and R. Nelson-Jones); spontaneity in deeds and sincerity in expressing their thoughts and feelings
(V.V. Stolin); the ability to clearly understand own feelings (K.K. Platonov). Therefore, the ability to clearly express their emotions, their identification of control is a significant characteristic of selfactualizing personality. Accordingly, the issue of studying emotional intelligence as a factor of selfactualization of personality has the considerable importance.

Presentation of the main research material. In the study of the subjects that are differently selfactualized features of emotional intelligence "Diagnostics of personality self-actualization" (A.V. Lazukin's inventory in the adaptation of N.F. Kalina (SAMOAL)) and "Questionnaire of emotional intelligence (EMI)" (D.V. Lucin) are used. The study was conducted on a sample of 75 persons, which included 2 subgroups. The first subgroup includes 45 persons who receive the second higher education in the specialty "Psychology", the second group - 30 persons, who paid attention to their own self-actualization - held courses in psychotherapy, training, practicing spiritual practices, etc. In our opinion, such groups of researched are the most suitable for studying the characteristics of self-actualization, because such representatives are interested in developing their potential, are concerned with this problem.

According to the results of the study, it was found that the majority $(87.5 \%)$ of the representatives are characterized by an average level of self-actualization (Fig. 1). Such respondents are able to determine their own capabilities, interests and values, and ways of their implementation. However, they often do not have a holistic vision of their own lives or are centered in some of its time intervals past or future $(50 \%)$, sometimes not having a sufficient level of spontaneity (25\%). This study is characterized, mainly, medium expressed ability to contact $(50 \%)$ and the need for knowledge and creativity $(56.25 \%)$.

The smaller part of the sample $(12.5 \%)$ has a high level of self-actualization. Such respondents self-actualized, are able to find a way to reconcile their desires and opportunities to realize them, satisfied with their own Self. They are able to live successfully today (50\%), take on themselves, others and life in general as a gift with all the negative and 
positive sides. This representatives has the inherent ability to live in the present, that is, to experience the present moment of life in its entirety, and not simply as a fatal consequence of the past or preparation for the future of "true life". They are able to feel the continuity of the past, present and future, that is, to see their life as a whole. Such attitude, psychological perception of time by respondents testifies to the high level of their self-actualization.

They are independent in their actions, they seek to be guided in their lives by their own goals, convictions, attitudes and principles (50\%), which, however, does not mean hostility to others and confrontation with group norms. They are free to choose, are not inclined to external influence, have an internal control locus. For these respondents flexibility of behavior and spontaneity of manifestations of their capabilities, the ability to creative expression and orientation on the knowledge of the new are inherent.

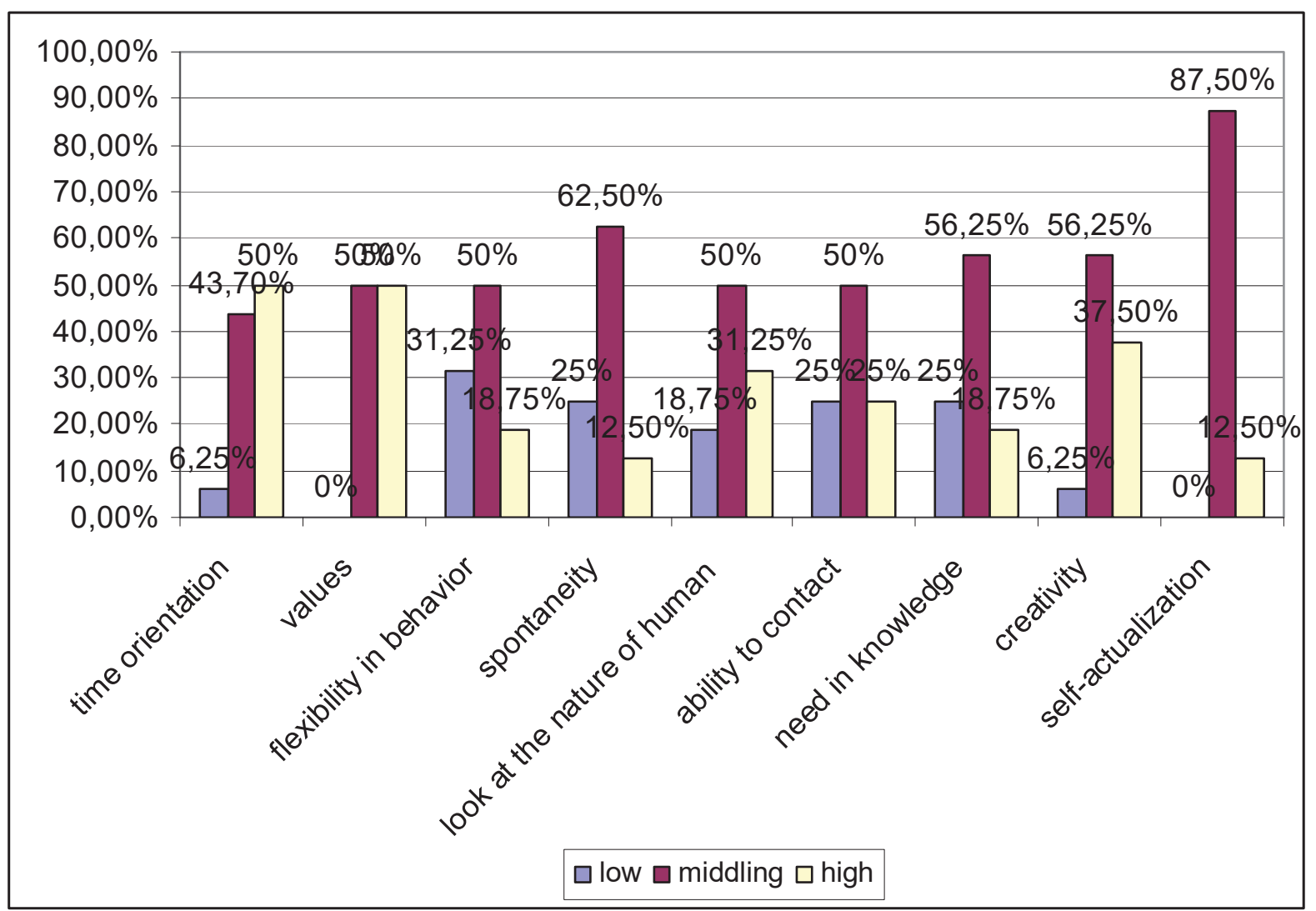

Figure 1. Indicators of self-actualization of the respondents

Analyzing group indicators, we can determine that the most pronounced characteristics of selfactualization of the respondents are time orientation, values, a view of human nature, creativity, flexibility. Thus, $50 \%$ of researched people live in the present, realizing their potential in it and not trying to live memories. Also, $50 \%$ of the group share the values of self-actualized personality, defined by Maslow, (2007) - kindness, integrity, vitality, justice, order, simplicity, etc. At the same time, $37.5 \%$ of the respondents are characterized by expressed at a high level creativity - the ability to create a new, creative combination of previously allocated parts of the problem, etc. For $31.25 \%$ of the sample representatives peculiar expressed faith in the nature of human - the confidence that the person is endowed with potential opportunities, able to develop and appropriate attitude to others.

Less expressed self-actualization parameters include flexibility in behavior $(31.25 \%$ of respondents have low quality levels), need for cognition and spontaneity ( $25 \%$, respectively).

Consideration of the emotional intelligence data in the two groups we studied is presented in Table 1. 
Table 1.

Indicators of emotional intelligence of the sample

\begin{tabular}{|c|c|c|c|}
\hline \multirow{2}{*}{ Indicators of emotional intelligence } & \multicolumn{3}{|c|}{ Level } \\
\cline { 2 - 4 } & low & middling & high \\
\hline The emotions of others understanding & $12,5 \%$ & $50 \%$ & $37,5 \%$ \\
\hline Others' emotions managing & $12 \%$ & $44 \%$ & $44 \%$ \\
\hline Own emotions understanding & $25 \%$ & $31 \%$ & $44 \%$ \\
\hline Own emotions managing & $25 \%$ & $31 \%$ & $44 \%$ \\
\hline Expression control & $25 \%$ & $19 \%$ & $56 \%$ \\
\hline Interpersonal emotional intelligence & $19 \%$ & $44 \%$ & $37 \%$ \\
\hline Intrapersonal emotional intelligence & $25 \%$ & $19 \%$ & $56 \%$ \\
\hline Emotions understanding & $19 \%$ & $44 \%$ & $37 \%$ \\
\hline Emotions managing & $25 \%$ & $12,5 \%$ & $62,5 \%$ \\
\hline Emotional intelligence & $19 \%$ & $12,5 \%$ & $68,5 \%$ \\
\hline
\end{tabular}

As shown in Table 2, the two studied groups have rather high levels of emotional intelligence. In particular, most of the respondents (68.5\%) are characterized by a high level of emotional intelligence, able to adequately understand their and others' emotions, and effectively manage them. Also, $12.5 \%$ of respondents have an average level of emotional intelligence, mostly correctly and adequately understand emotions, manage them, but often they may be wrong or not fully understand the meaning of emotional phenomena, paying more attention to cognitive processes and phenomena. Also, the minority (19\%) of the respondents who focus on their own self-actualization, have a low level of emotional intelligence, are unable to correctly identify emotions and effectively manage them in interpersonal interaction and intrapsychic life. Consequently, the self-actualized adults of an adult age, mainly, are characterized by elevated indicators of emotional intelligence.

It has been determined that respondent's intrapersonal emotional intelligence is higher (high level is inherent in 56\%) than interpersonal (high level is recorded in 37\%). That is, the respondents are better at identifying their own emotions, regulating their course, than understanding the emotional experiences of others, staying with them in emotional resonance. At the same time, the representatives of the sample considerably better control their emotions (a high level of $62.5 \%$ ) than they understand it (37\%). They have developed clear patterns of emotional self-control in accordance with social standards and expectations, which, however, impedes them in the process of self-actualization.

In general, we recorded similar indicators of severity of certain aspects of emotional intelligence in the sample. In particular, $44 \%$ of the respondents have a high level of others and their emotions control, understanding the content of their own emotional sphere. Also, $56 \%$ of respondents have a high level of control over their own emotional experiences and $37.5 \%$ - a high level of understanding of others' emotions. Low levels of certain aspects of emotional intelligence indicators are characteristic for a small proportion of the respondents and range from $12 \%$ to $25 \%$.

Thus, the study of both groups is characterized by the predominance of elevated emotional intelligence indicators, especially its regulatory component in the internal intrapersonal aspect.

Also we compare the emotional intelligence indicators among the two subgroups, because we predict that this quality expressiveness level engaged in self-development and students of the second higher education may differ in view of various motivational trends in their self-development or education. These data are presented in Table 2. 
Table 2.

Indicators of emotional intelligence of the respondents who receive the second higher education

$\left(1^{\text {st }}\right.$ subgroup $)$ and are engaged in self-development ( $2^{\text {nd }}$ subgroup $)$

\begin{tabular}{|c|c|c|c|c|c|}
\hline \multirow{2}{*}{$\begin{array}{c}\text { Indicators of emotional } \\
\text { intelligence }\end{array}$} & \multirow{2}{*}{ Subgroup } & \multicolumn{3}{|c|}{ Level } & \multirow{2}{*}{$t$} \\
\hline & & low & middling & high & \\
\hline \multirow{2}{*}{$\begin{array}{c}\text { The emotions of others } \\
\text { understanding }\end{array}$} & $1^{\text {st }}$ & $22 \%$ & $33 \%$ & $45 \%$ & \multirow{2}{*}{$3,310^{* *}$} \\
\hline & $2^{\text {nd }}$ & $0 \%$ & $71 \%$ & $29 \%$ & \\
\hline \multirow{2}{*}{ Others' emotions managing } & $1^{\text {st }}$ & $22 \%$ & $33 \%$ & $45 \%$ & \multirow{2}{*}{$2,221 *$} \\
\hline & $2^{\text {nd }}$ & $0 \%$ & $57 \%$ & $43 \%$ & \\
\hline \multirow{2}{*}{ Own emotions understanding } & $1^{\text {st }}$ & $22 \%$ & $33 \%$ & $45 \%$ & \multirow{2}{*}{0,575} \\
\hline & $2^{\text {nd }}$ & $29 \%$ & $29 \%$ & $42 \%$ & \\
\hline \multirow{2}{*}{ Own emotions managing } & $1^{\text {st }}$ & $22 \%$ & $22 \%$ & $56 \%$ & \multirow{2}{*}{1,287} \\
\hline & $2^{\text {nd }}$ & $29 \%$ & $42 \%$ & $29 \%$ & \\
\hline \multirow{2}{*}{ Expression control } & $1^{\text {st }}$ & $22 \%$ & $22 \%$ & $56 \%$ & \multirow{2}{*}{0,285} \\
\hline & $2^{\text {nd }}$ & $29 \%$ & $14 \%$ & $57 \%$ & \\
\hline \multirow{2}{*}{$\begin{array}{l}\text { Interpersonal emotional } \\
\text { intelligence }\end{array}$} & $1^{\text {st }}$ & $33 \%$ & $33 \%$ & $34 \%$ & \multirow{2}{*}{$2,57^{*}$} \\
\hline & $2^{\text {nd }}$ & $0 \%$ & $57 \%$ & $43 \%$ & \\
\hline \multirow{2}{*}{$\begin{array}{c}\text { Intrapersonal emotional } \\
\text { intelligence }\end{array}$} & $1^{\text {st }}$ & $22 \%$ & $11 \%$ & $67 \%$ & \multirow{2}{*}{0,889} \\
\hline & $2^{\text {nd }}$ & $29 \%$ & $29 \%$ & $42 \%$ & \\
\hline \multirow{2}{*}{ Emotions understanding } & $1^{\text {st }}$ & $22 \%$ & $33 \%$ & $45 \%$ & \multirow{2}{*}{1,357} \\
\hline & $2^{\text {nd }}$ & $14 \%$ & $57 \%$ & $29 \%$ & \\
\hline \multirow{2}{*}{ Emotions managing } & $1^{\text {st }}$ & $22 \%$ & $22 \%$ & $56 \%$ & \multirow{2}{*}{0,165} \\
\hline & $2^{\text {nd }}$ & $29 \%$ & $0 \%$ & $71 \%$ & \\
\hline \multirow{2}{*}{ Emotional intelligence } & $1^{\text {st }}$ & $22 \%$ & $0 \%$ & $78 \%$ & \multirow{2}{*}{0,757} \\
\hline & $2^{\text {nd }}$ & $14 \%$ & $29 \%$ & $57 \%$ & \\
\hline
\end{tabular}

As shown in Table 2, there is a straight distinction between the two groups of participants in the interpersonal emotional intelligence expression ( $\mathrm{t}$ $=2.57, \mathrm{p} \leq 0.05)$ and its components - others' emotions understanding $(\mathrm{t}=3.310, \mathrm{p} \leq 0.01)$ and others' emotions managing ( $\mathrm{t}=2,221, \mathrm{p} \leq 0,05)$. Moreover, according mathematical statistics data, these characteristics are more inherent (by comparison of mean values) to a group of people paying attention to their own self-actualization, despite the fact that the percentage of high-level characteristics of others emotions understanding and managing among the representatives of second higher education group are higher. This can be explained by the prevalence of average and high levels in the group of self-actualized ones, along with a greater dispersion of interest rates in the second highest group. That is, personalities engaged in own self-actualization, characterized by a more pronounced indicator of interpersonal emotional intelligence, the ability to perceive, understand and interpret the emotions of others, and manage them in the process of interpersonal interaction.

According to other indicators of emotional intelligence between the groups of the second higher education and those who engaged in selfactualization, the statistical difference is absent. That is, they equally understand their own emotions at the elevated level, control emotional experiences and their expression, characterized by increased levels of emotional intelligence. Representatives of the sample who receive second higher education have some higher percentage values for managing their emotions and their understanding, which, however, do not have a statistically significant difference.

Conclusions and perspectives of further exploration in this field. The role of emotional intelligence in the process of self-actualization of the 
adult's age is attributed to the definite characteristics of self-actualized personality that relate to the sphere of emotional life (higher experiences, the ability to spontaneous behavior and expression of their feelings, the adoption of aggression as a natural manifestation of human nature, openness as an expression of the desire to love and to cause love , emotionality, immediacy in actions and sincerity in expressing their thoughts and feelings, the ability to understand their own feelings).

Empirical data analysis gave us the opportunity to conclude that both group respondents are characterized by high enough indicators of emotional intelligence. In particular, most of the respondents are characterized by a high level of emotional intelligence, capable of an adequate understanding of their and others' emotions, and effective it management. It is determined that for the entire sample the intrapersonal emotional intelligence is mare inherent than interpersonal. That is, personalities engaged in own self-actualization, characterized by a more pronounced indicator of interpersonal emotional intelligence, the ability to perceive, understand and interpret the emotions of others, and manage them in the process of interpersonal interaction.
The prospect of further research is the study of the connection between the process of self-actualization of the person and its peak experiences, which will enable to explore new factors of self-actualization of the individual.

\section{REFERENCES}

Goulman, D. (2009). Емоииональный интеллект [Emotional intelligence]. Moscow: ACT MOSKVA; Vladimir: VKT [in Russian].

Maslow, A. (2007). Мотивация и личность [Motivation and personality]. Sankt-Petersburg: Piter [In Russian].

Sedykh, K.V. (2016). Дослідження репрезентації соціальнополітичної кризи в суспільній свідомості жителів України в системі системно-синергетичного підходу [Research of the representation of the socio-political crisis in the public consciousness of the inhabitants of Ukraine in the system-synergistic approach]. Psykholohiia $i$ osobystist. [Psychology and personality], 1, 53-69 [in Ukrainian].

Sergienko, E.A. (2010). Test Dzh. Mjejera, P. Sjeloveja, D. Karuzo "Jemocional'nyj intellekt" (MSCEIT v. 2.0): Rukovodstvo [Questionnaire of emotional intelligence by J. Meyer, P. Salovey and D. Caruso (MSCEIT v. 2.0): Manual]. Moscow: Izd-vo "Institut psihologii RAN" [in Russian].

Starins'ka, N.V. (2015). Особливості самоактуалізаиіï майбутніх психологів в процесі професійної роботи [Features of self-actualization of future psychologists in the process of professional training]. Kyiv: "Interservis" [In Ukrainian].

\section{РОЛЬ ЕМОЦІЙНОГО ІНТЕЛЕКТУ В САМОАКТУАЛІЗАЦІЇ ОСОБИСТОСТІ \\ Милашенко К.O.}

аспірант кафедри психології

Полтавський національний педагогічний університет імені В. Г. Короленка

Лавриненко В.А.

кандидат психологічних наук, доцент кафедри психології

Полтавський національний педагогічний університет імені В. Г. Короленка

Стаття присвячена аналізу ролі емоційного інтелекту у процесі самоактуалізації особистості дорослого віку. Описано актуальність вивчення зв'язку емоційного інтелекту та самоактуалізації в контексті сучасних наукових дискурсів та кризових умов суспільства. Стаття містить узагальнення результатів теоретичного аналізу проблеми самоактуалізації. Подано найбільш суттєві ознаки процесу самоактуалізації з точки зору гуманістичної психології та описано методологічні засади й основні аспекти розуміння самоактуалізації у вітчизняній психології згідно методологічних принципів діяльнісного підходу. Визначено сутнісні ознаки емоційного інтелекту особистості, його структура. Обгрунтовано, що емоційний інтелект має зв'язок із процесом самоактуалізації особистості через реалізацію особистості у повноті власного емоційного життя, спроможності до переживання пікових емоцій, контролю змісту емоційної сфери, тощо. Описано методичні засади дослідження, специфіку вибірки та порівнюваних діагностичних груп. Проаналізовані емпіричні дані вивчення самоактуалізації досліджуваних, найбільш значимі iї параметри, вираженості у досліджуваних різних аспектів емоційного інтелекту. Отримані емпіричні дані інтерпретовано відповідно до класичних та сучасних наукових поглядів на природу процесів самоактуалізації та емоційного інтелекту. Інтерпретовано вираженість показників емоційного інтелекту в інтра- та інтерперсональній площині у двох групах досліджуваних - респондентів, які здобувають другу вищу освіту за спеціальністю «Психологія», і досліджуваних, що мають на меті самоактуалізуватися. Статистично обгрунтоване та змістовно аналізоване переважання міжособистісного емоційного інтелекту та його компонентів - розуміння чужих емоцій і управління чужими емоціями у представників вибірки, що мають на меті власну самоакуталізацію. Також, виявлено загально виражену для обох груп досліджуваних тенденцію до ідентифікації змісту власної емоційної сфери, ії експресії та показника емоційного 
інтелекту загалом. На основі узагальнення емпіричних даних виявлено тенденцію поєднання ознак самоактуалізації та емоційного інтелекту в функціонуванні особистості.

КЛЮЧОВІ СЛОВА: самоактуалізація особистості, чинники самоактуалізації, орієнтація в часі, емоційний інтелект, міжособистісний та внутрішньоособистісний емоційний інтелект, емоційний інтелект як чинник самоактуалізації

РОЛЬ ЭМОЦИОНАЛЬНОГО ИНТЕЛЛЕКТА В САМОАКТУАЛИЗАЦИИ ЛИЧНОСТИ

К.О. Милашенко

аспирант кафедры психологии,

Полтавский Начиональный педагогический университет имени В.Г. Короленко

В.А. Лавриненко

кандидат психологических наук, доцент кафедры психологии

Полтавский национальный педагогический университет имени В.Г. Короленко

Статья посвящена анализу роли эмоционального интеллекта в процессе самоактуализации личности взрослого возраста. Описаны актуальность изучения связи эмоционального интеллекта и самоактуализации в контексте современных научных дискурсов и в кризисных условиях общества. Статья содержит обобщение результатов теоретического анализа проблемы самоактуализации. Представлены наиболее существенные признаки процесса самоактуализации с точки зрения гуманистической психологии и описаны методологические основы и основные аспекты понимания самоактуализации в отечественной психологии согласно с методологическими принципами деятельностного подхода. Определены сущностные признаки эмоционального интеллекта личности, его структура. Обосновано, что эмоциональный интеллект имеет связь с процессом самоактуализации личности через реализацию личности в полноте собственной эмоциональной жизни, способности к переживанию пиковых эмоций, контроля содержания эмоциональной сферы. Описаны методические основы исследования, специфика выборки и сравниваемых диагностических групп. Проанализированы эмпирические данные изучения самоактуализации испытуемых, наиболее значимые ее параметры, выраженность у испытуемых различных аспектов эмоционального интеллекта. Полученные эмпирические данные интерпретированы в соответствии с классическими и современными научными взглядами на природу процессов самоактуализации и эмоционального интеллекта. Интерпретирована выраженность показателей эмоционального интеллекта в интра- и интерперсональной плоскости в двух группах испытуемых - респондентов, получающих второе высшее образование по специальности «Психология», и испытуемых, имеющих целью самоактуализироваться. Статистически обоснованно и содержательно проанализировано преобладание межличностного эмоционального интеллекта и его компонентов - понимания чужих эмоций и управления чужими эмоциями у представителей выборки, имеющих целью собственную самоакутализацию. Также, обнаружено выраженную для обеих групп испытуемых тенденцию к идентификации содержания собственной эмоциональной сферы, ее экспрессии и показателя эмоционального интеллекта в целом. На основе обобщения эмпирических данных выявлена тенденция сочетания признаков самоактуализации и эмоционального интеллекта в функционировании личности.

КЛЮЧЕВЫЕ СЛОВА: самоактуализация личности, факторы самоактуализации, ориентация во времени, эмоциональный интеллект, межличностный и внутриличностный эмоциональный интеллект, эмоциональный интеллект как фактор самоактуализации 